補綴誌, J Jpn Prosthodont Soc, 37：26〜40, 1993.

原著論文

\title{
連結固定が歯牙の変位様相に及ぼす影響
}

古木 譫

\section{The Effect of Splinting on the Tooth Displacement}

\section{Yuzuru Furuki}

\begin{abstract}
Upper second premolar and first and second molars were splinted without any changes of occlusal tooth contacts and interdental proximal contact relations. Each of 4 subjects was instructed to clench, bite 4 or 8 articulating papers and masticate a piece of pretzel. The displacement of upper second premolar and first molar was recorded on a horizontal plane at the same point before and after splinting.

As a result, the amount of displacements of upper second premolars of the 4 subjects was changed $-25 \sim+27 \mu \mathrm{m}$ in length and $-22 \sim+8^{\circ}$ in angle by splinting. That of first molars was changed $1 \sim 29 \mu \mathrm{m}$ in length and $-10 \sim+31^{\circ}$ in angle. These changes, however, were not remarkable compared with the range of physiological tooth displacement. Thus, splinting of approximately three teeth does not disturb periodontium.
\end{abstract}

Key words: splinting, tooth displacement

\section{I. 緒 言}

歯牙は機能時に咬合力を受けて歯周組織の物性に由 来する変位を示す．この歯牙の変位機構は咬合力の筫 骨への直接の伝播を緩衝するとともに，歯牙自体が受 ける力をも緩衝している，機能時に生ずる歯牙の変位 の様相を明らかにすることは，歯の支持機構と咬合と の関係の解明あるいは歯の支持組織の病態診断とも関 わっており, Mühlemann" ${ }^{11}$ 以来, Siebert ${ }^{2,31}$, 加 藤 4,5$)$, 三浦6,7)らの研究があって, 個々の歯牙の歯周 組織の動態はかなりの程度まで明らかとなっている。

一方, 補経学の臨床においては歯牙欠損に対してブ リッジによる補緅を行うために歯牙を連結固定するこ とがある．このとき機能時の歯牙の変位がどのような

東京医科歯科大学歯学部第 2 歯科補緅学教室（主任・指導： 田端恒雄教授)

Department of Prosthodontics II, Faculty of Dentistry, Tokyo Medical and Dental University (Chief and Director: Prof. Tsuneo Tabata)

平成 4 年 9 月 7 日受付
影響を受けるのかという問題はなお不明のままに残さ れているが，これはブリッジ補緅の成否とも関連する 重要な研究課題である.

そこで，著者は複数の歯牙を連結固定して，連結固 定の前後における歯牙の変位, 歯周組織の動態を比較 検討することとした。

\section{II. 研究方法}

上額右側第 2 小臼歯，第 1 大臼歯，第 2 大臼歯の 3 歯を連結固定する前後において, 機能時の第 2 小臼 歯, 第 1 大臼歯の水平面内での変位を 2 次元微小変位 計 $\mathrm{M}-\mathrm{r}$ 型を用いて測定する。

\section{1. 被験歯}

被験歯は 25〜27 歳の男性 4 名の上箱右側第 2 小臼 歯および第 1 大臼歯で, インレーによる修復処置が行 われている歯牙もあるが，歯周組織の状態は臨床的に 健全である（表 1 , 図 1 )。

歯牙の変位の測定点は, 各被験歯の煩側歯頸部中央 
表 1 被 験 者

\begin{tabular}{c|cc|cc|c}
\hline \hline \multirow{2}{*}{} & \multirow{2}{*}{ 性別 } & \multirow{2}{*}{ 年齢 } & \multicolumn{3}{|c|}{ 修復物などの有無 } \\
\cline { 4 - 6 } & & & $\underline{5}$ & $\underline{6}$ \\
\hline $\mathrm{A}$ & $\hat{\delta}$ & 25 & な & し & 1 級インレー \\
$\mathrm{B}$ & $\hat{\delta}$ & 26 & な & し & な \\
$\mathrm{C}$ & $\hat{\delta}$ & 26 & な & し & 1 級インレー \\
$\mathrm{D}$ & $\hat{\delta}$ & 27 & な & し & な \\
\hline
\end{tabular}
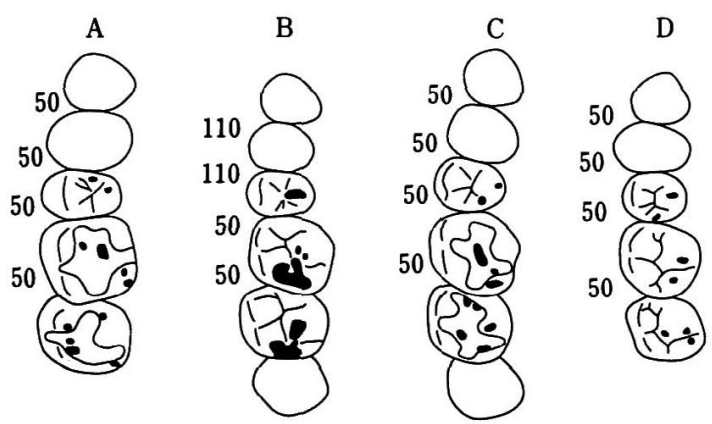

図 1 咬合接触状態および歯間雕開度 $(\mu \mathrm{m})$

の天然歯面上に設定した厚さ約 $1 \mathrm{~mm}$ の標点である.

\section{2. 歯牙の連結固定}

1）連結固定装置の構造

上額右側第 2 小臼歯，第 1 大臼歯および第 2 大臼歯 を一体として連結固定する連結固定装置は，歯牙の機 能時の咬合接触を妨げないように咬合面を覆わない頓 側面板と口蓋側面板とからなる (図 2 ). 口蓋側面板 は各歯牙の口蓋側全体を覆うように作製されている が, 頓側面板は第 2 小臼歯, 第 1 大臼歯に設定した歯 頸部の標点を避けるような構造となっている（図 3 ). また，煩側面板，口蓋側面板とも隣接接触関係を乱さ ないように各隣接接触点からは十分に離してある.

連結固定装置はシリコーンラパー印象材*1で印象採 得を行い, 超硬石膏*2を注入した被験者の歯列模型に よって間接法で作製する，軟化したワックス*3を歯列 模型に圧接して厚さ約 $1.5 \mathrm{~mm}$ の連結固定装置の蠟型 を採得し，通法に従ってタイプIV金合金“4にて鋳造し た後に硬化熱処理を行う。

・(株)ジーシー：ハイドロフィリックエクザフレックス（イン ジェクションタイプ, パテタイプ)

*2 KERR SYBRON : Vel-Mix Stone

*3 (株) ジーシー: ブルーインレーワックス

*4 (株) ジーシー：キャスティングゴールド M.C.タイプIV

*s Bayer Dental : XANTHANO

*6 東亜合成化学：ボンドアロンアルファ

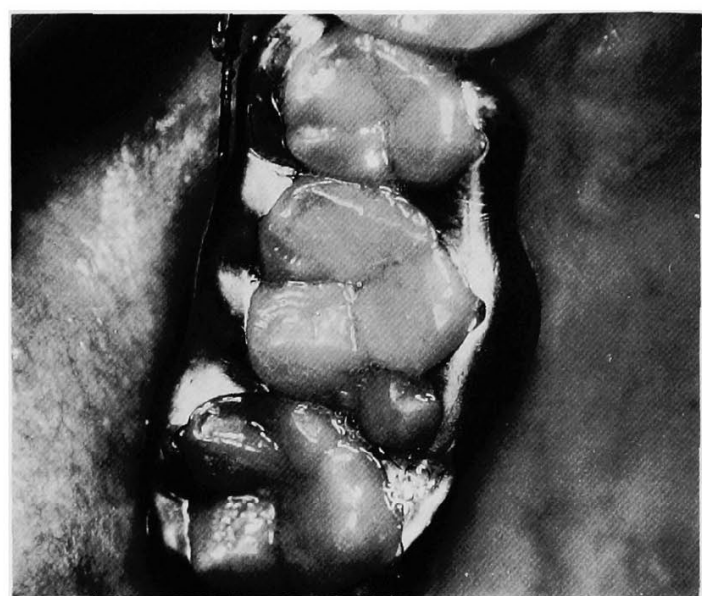

図 2 連結固定装置 (咬合面観)

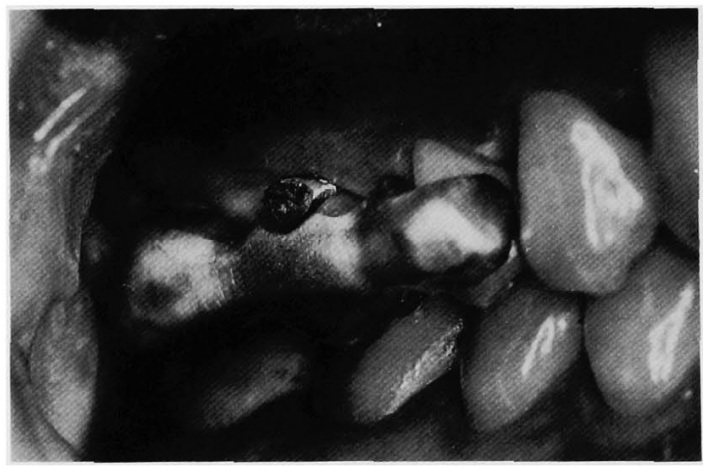

図 3 連結固定装置の類側面板

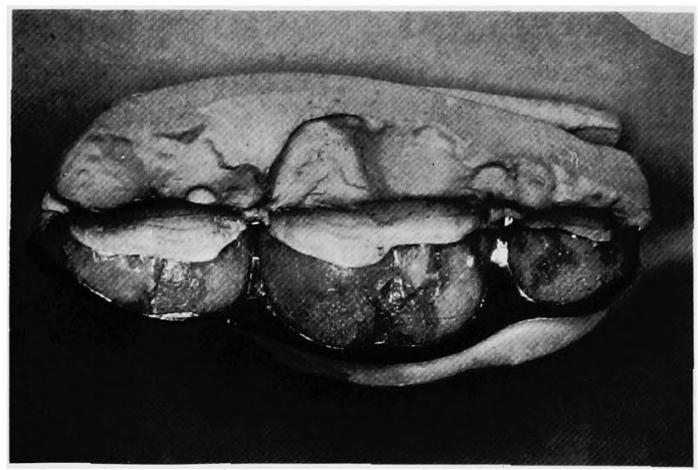

図 4 連結固定装置を嵌合した石骨コア

2) 歯牙の連結固定方法

歯牙の連結固定は石亮コア*5を用いて行う. 歯列模 型上に連結固定装置を試適して，煩側面板と咬合面を 覆う石高コア，口蓋側面板と咬合面を䧈う石育コアを 採得する。この石膏コアに連結固定装置を嵌合し（図 4 ), シアノアクリレート系接着剤*6を固定装置の内 


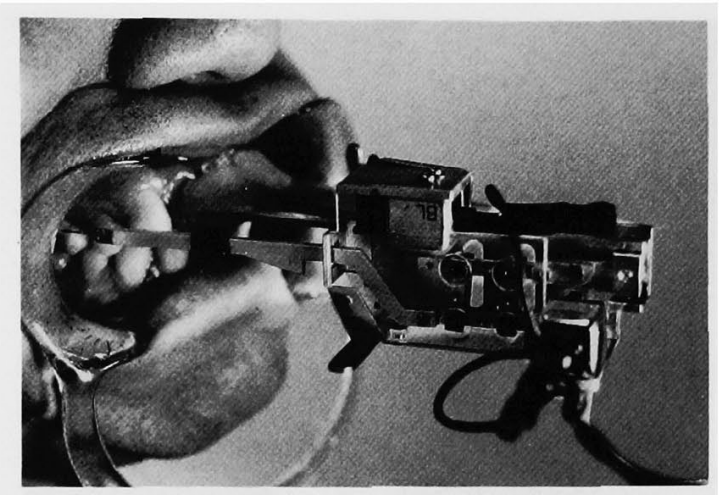

图 52 次元微小変位計 M-r 型ヘッド部

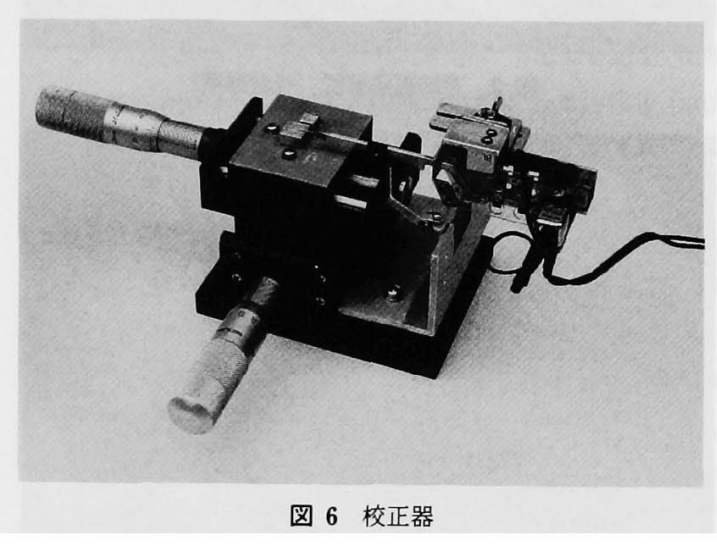

面に塗布して, 口腔内の歯牙に圧接, 接着し, 石膏コ アを除去して，煩側面板と口蓋側面板とで右側上䪽第 2 小臼歯, 第 1 大臼歯, 第 2 大臼歯の 3 歯の連結固定 を行う。

\section{3. 歯牙の变位の測定}

1) 2 次元微小変位計 $M-r$ 型

歯牙の水平面内での変位の測定には三浦の 2 次元微

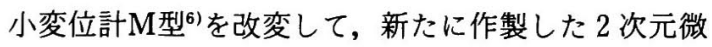
小変位計 $\mathrm{M}-\mathrm{r}$ 型を用いる. 本変位計の基本構造, 卜 ランスデューサなどはM型に準じたものであるが，口 腔内定位装置の固定板には右側臼歯部での歯牙の変位 の測定に適するような変更を加えてある（図 5 ）。

\section{2）測定精度}

変位計のキャリブレーションは水平面において互い に直角な X 軸, $\mathrm{Y}$ 軸方向に最小目盛 $10 \mu \mathrm{m}$ ，送り精 度 $\pm 1 \mu \mathrm{m}$ の校正器*7 を用いて行った（図 6 ). 本変位 計は近遠心, 頓舌方向ともに相互干渉はほとんどな

*7 (有)共和理研：マニピュレーターK-20-M 2

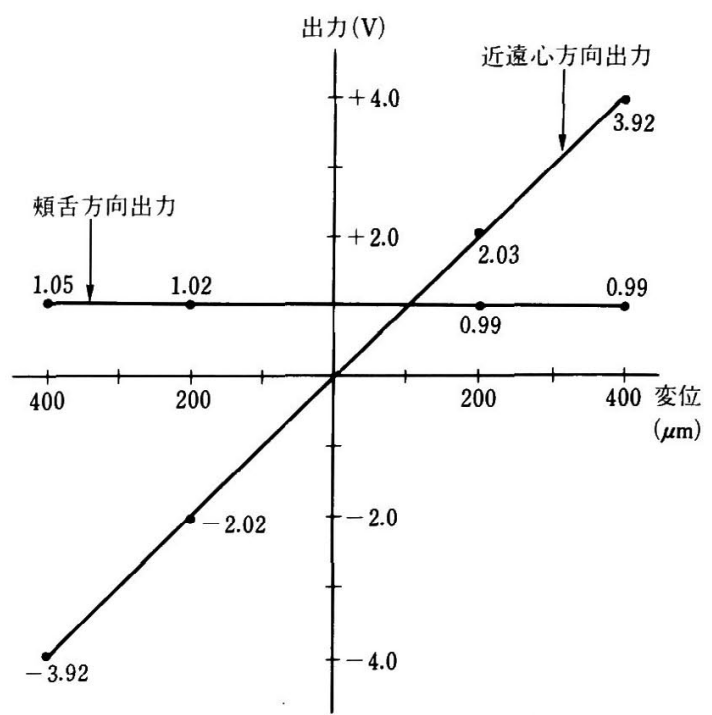

図 $7 \mathrm{M}-\mathrm{r}$ 型変位計の特性（近遠心方向変位時）

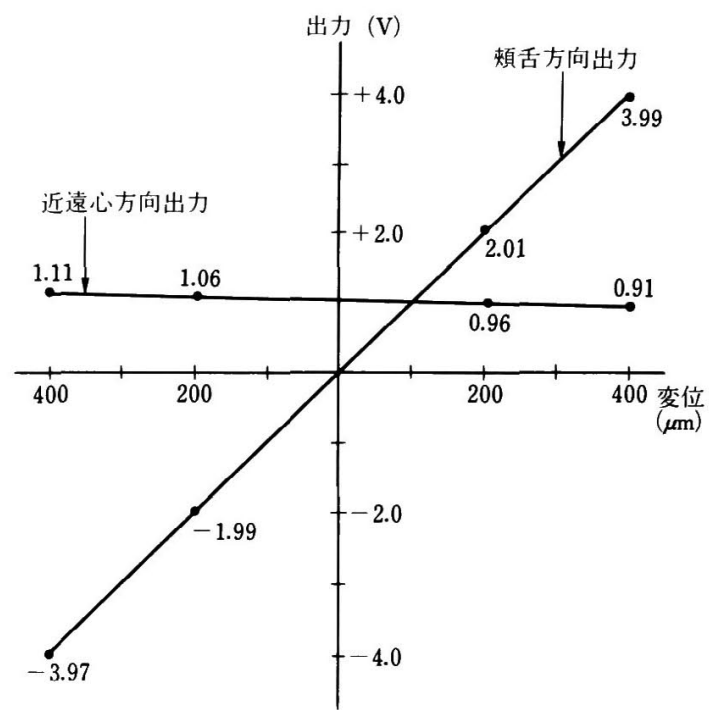

图 8 M-r 型変位計の特性（煩舌方向変位時）
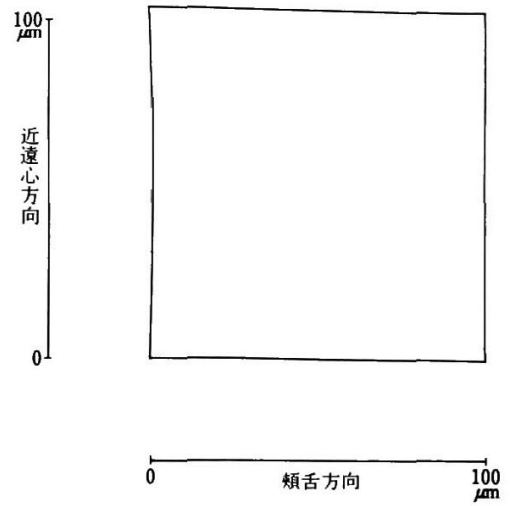

图 $9 M-r$ 型変位計の 2 次元特性 


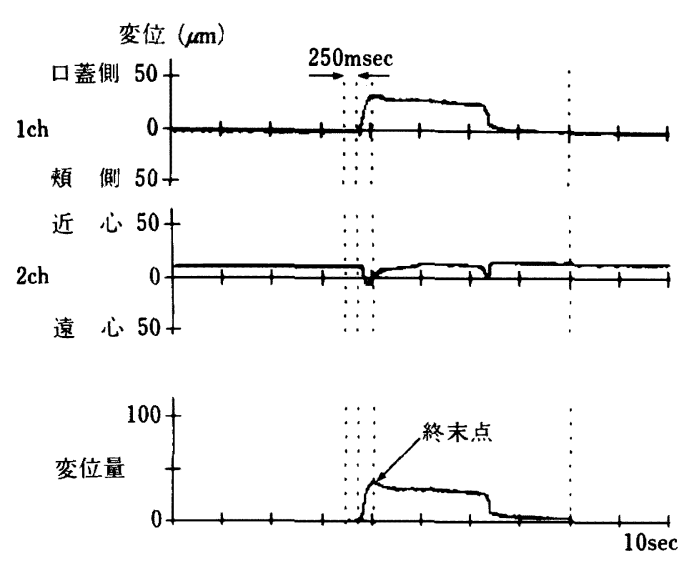

图 10 原点および変位量の求め方

く，それぞれの方向で $\pm 400 \mu \mathrm{m}$ の範囲内において $2 \%$ の精度でリニアな出力を示した（図 7〜9）。

\section{4. 測定項目}

歯牙の連結固定の前後に以下の項目について変位の 測定を行う.

1）嚙みしめ時

(1) 咬頭嵌合位

(2) 咬合紙*8

被験側臼歯部で約 2 秒間，咬合紙を 4 枚あるいは 8 枚嚙みしめる。

2) プリッツ咀嚼時

長さ約 $2 \mathrm{~cm}$ のプリッッ片*9を下䝷右側第 1 大臼歯 の中央部に置いて咀嚼を行わせ, 初期数ストロークを 測定対象とする.

\section{5. デー夕処理方法}

変位計のアンプ部からの出力はレクチグラブ*10に より確認しながら，すべてデータレコーダ*11に 10 $\mathrm{mv} / \mu \mathrm{m}$ で収録する。

データレコーダからの出力は X-Yレコーダ*12に入 力して変位経路を 2 次元表示するとともに, シグナル プロセッサ*13にサンプリングクロック $2.5 \mathrm{msec} て ゙$ 取 り込み,米牙の変位の原点, 変位量と変位方向を求める.

*8 (株) ジーシー:アーティキュレイティングペーパー（赤） *9 江崎グリコ(株) : プリッッ サラダ

*10 三栄測器(株) : RECTI-HORIZ-8 K 21

*11ソニーマグネスケール(株)：エルカセットデータレコーダ FE-39 A

*12 渡辺測器 (株) : X-Y レコーダ WX 4401

・13 三栄測器 (株)：シグナルプロセッサ7 T-17

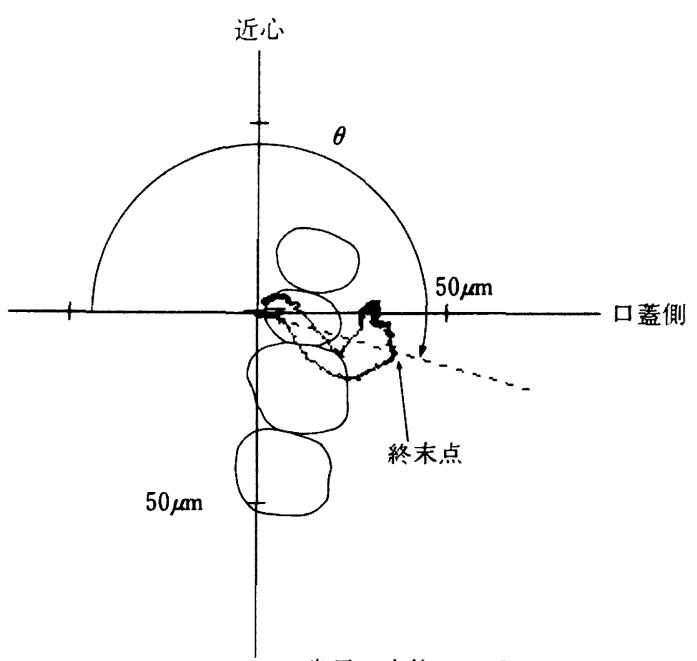

霜牙: 変位 $=1: 500$

图 11 変位方向の計測方法

\section{1）変位の原点}

嚙みしめ直前で歯牙が負荷を受けていない安定した 標点の位置を歯牙の原点とする.この条件に該当する $250 \mathrm{msec}$, すなわち 100 ポイントの区間をCRT上で 検出し, その区間の平均電位をもって原点とする（図 10).

2）変位量および変位方向

原点と変位経路上の各点との直線距離をすべて求 め, その中で最大值を示す点を終末点とし, この点の 座標から変位量と変位方向を算出する.変位方向は図 11 に示すように, 原点と変位の終末点とを結ぶ直線 が，原点において歯牙の煩側面に対して引いた接線の 法線と近心方向になす角度によって表し, 変位量は原 点から変位の終末点までの直線距離で表す。

\section{III. 結 果}

上顎右側第 2 小曰雬, 第 1 大臼歯, 第 2 大臼歯の 3 歯を連結固定装置で連結固定する前後での第 2 小臼 歯, 第 1 大臼歯の 2 歯の嚙みしめ時およびプリッツ咀 緭時の水平面内における変位の測定を行い, 変位量, 変 位方向および変位経路の分布範囲について以下の結果 を得た（図 12〜15, 表 2〜 5). なお，変位量と変位方向は， 嚙みしめ時については各 2 回の平均值で, プリッッ咀 噃時については初期数ストロークの中での最大 の変位量を示した経路の変位量と変位方向で表した。 
咬頭嵌合位

咬合紙 4 枚

咬合紙 8 枚

プリッツ咀啤

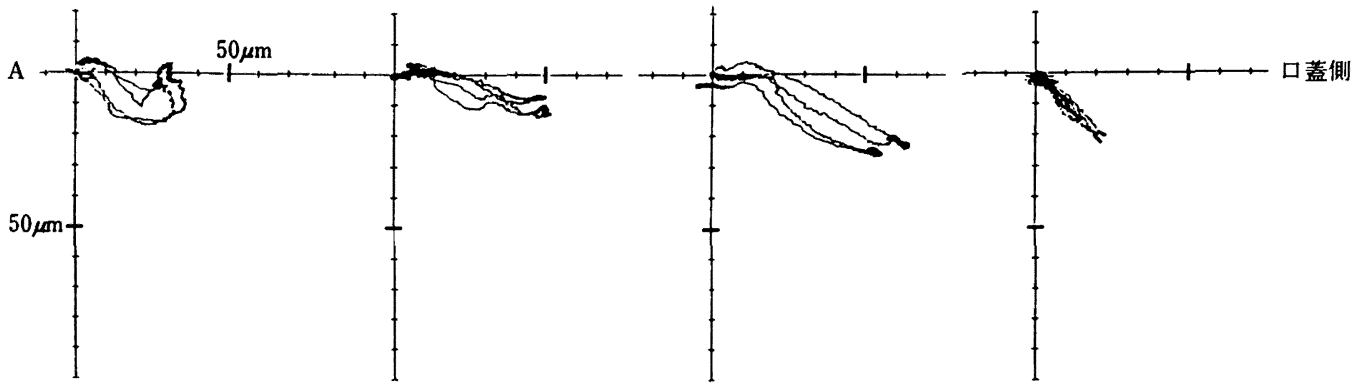

遠心
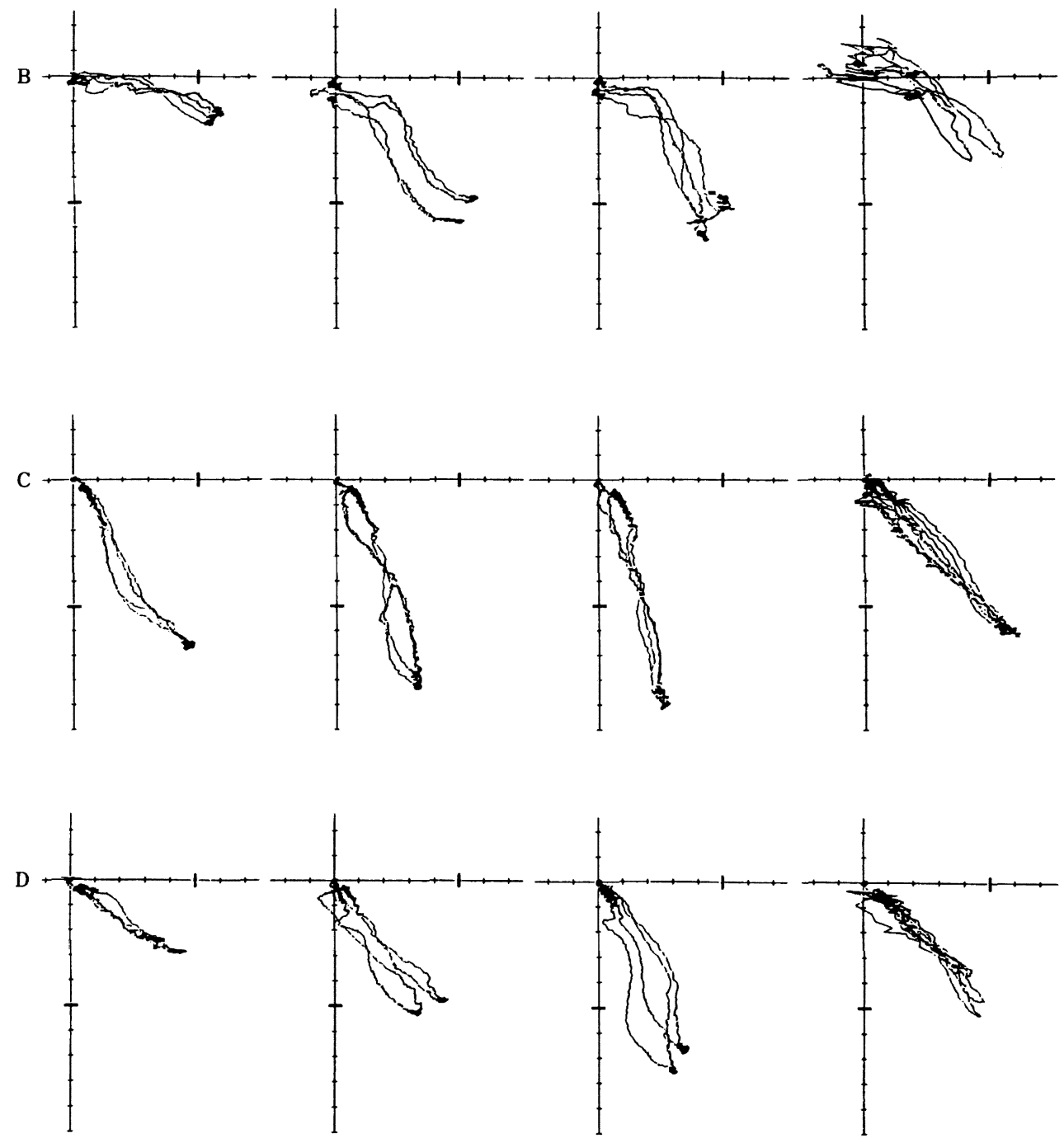

図 12 連結固定前の機能時の変位経路（上頸右側第 2 小臼歯） 
咬頭嵌合位

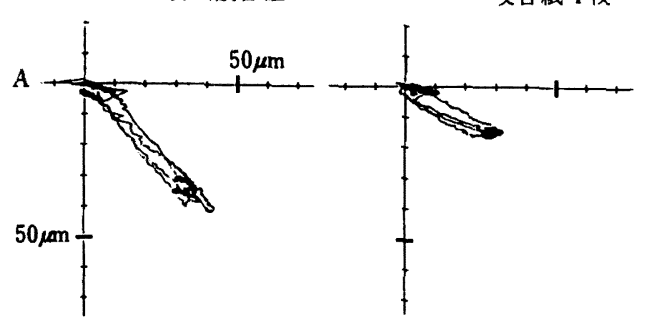

遠心
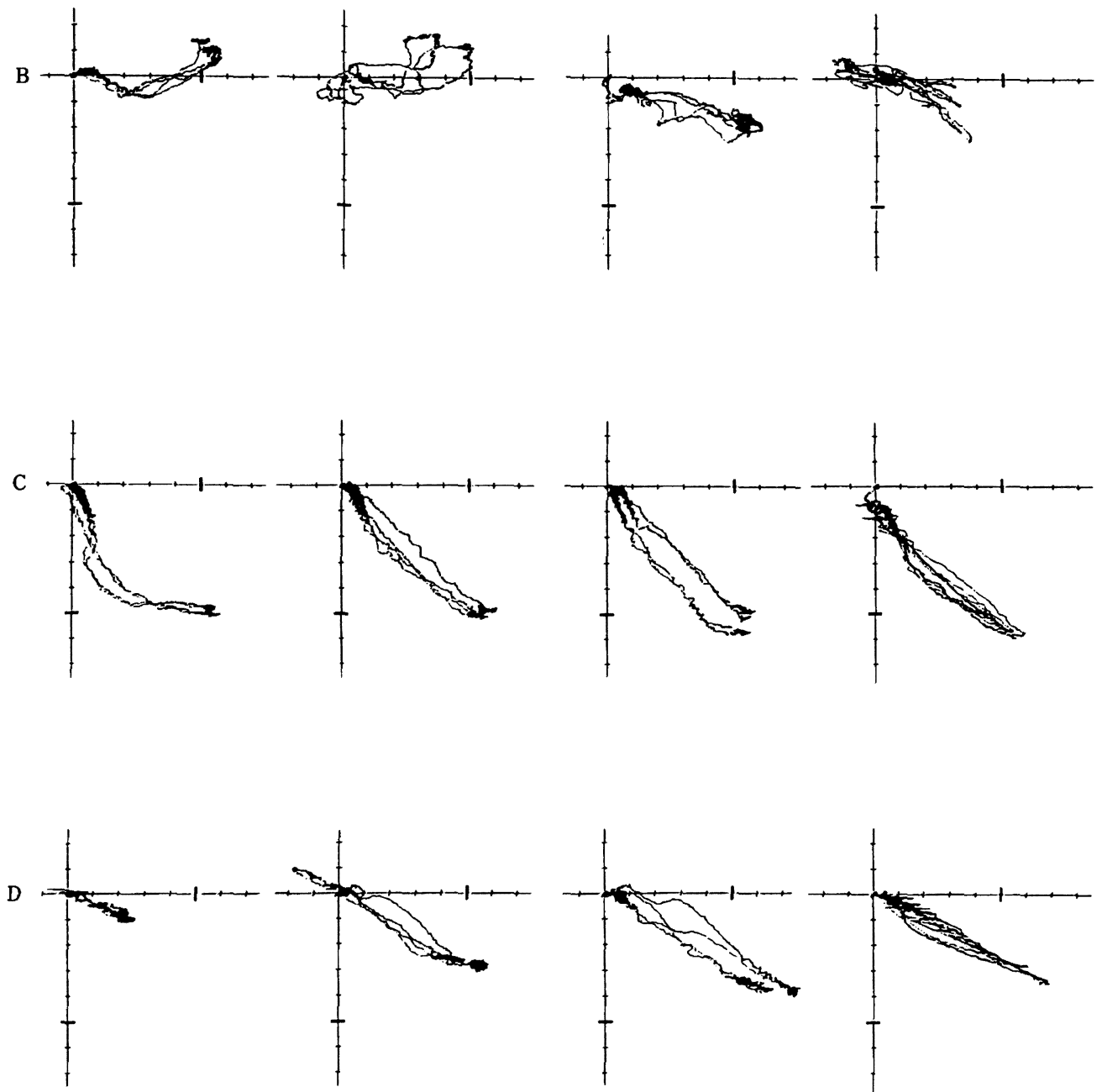

図 13 連結固定前の機能時の変位経路（上額右側第 1 大臼崡）
プリッツ咀㗑

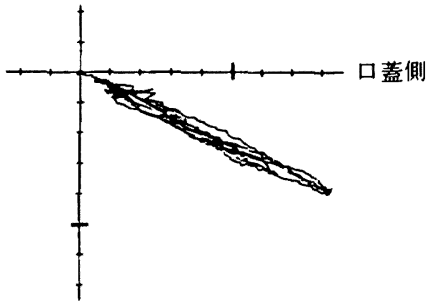




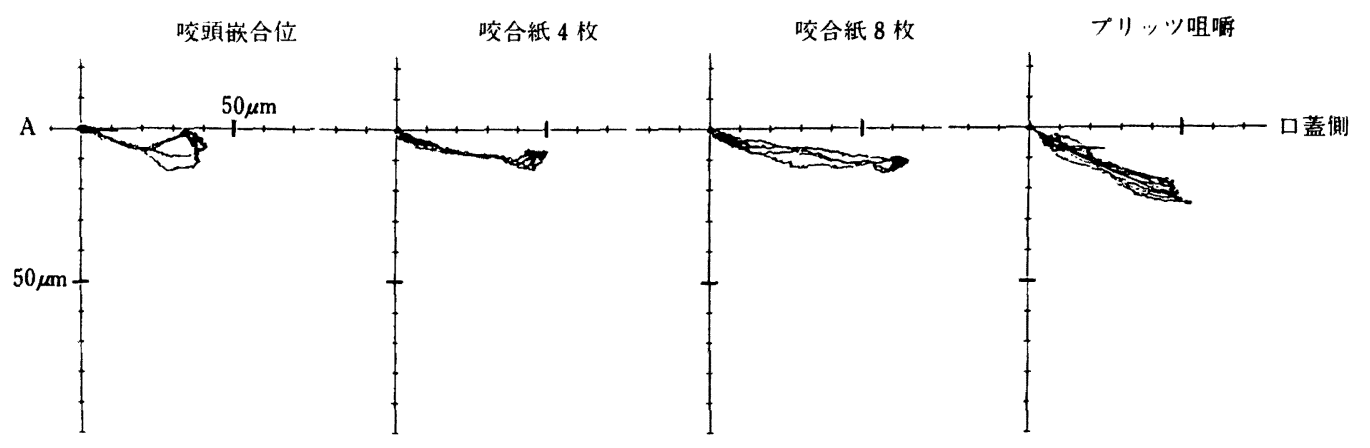

遠心
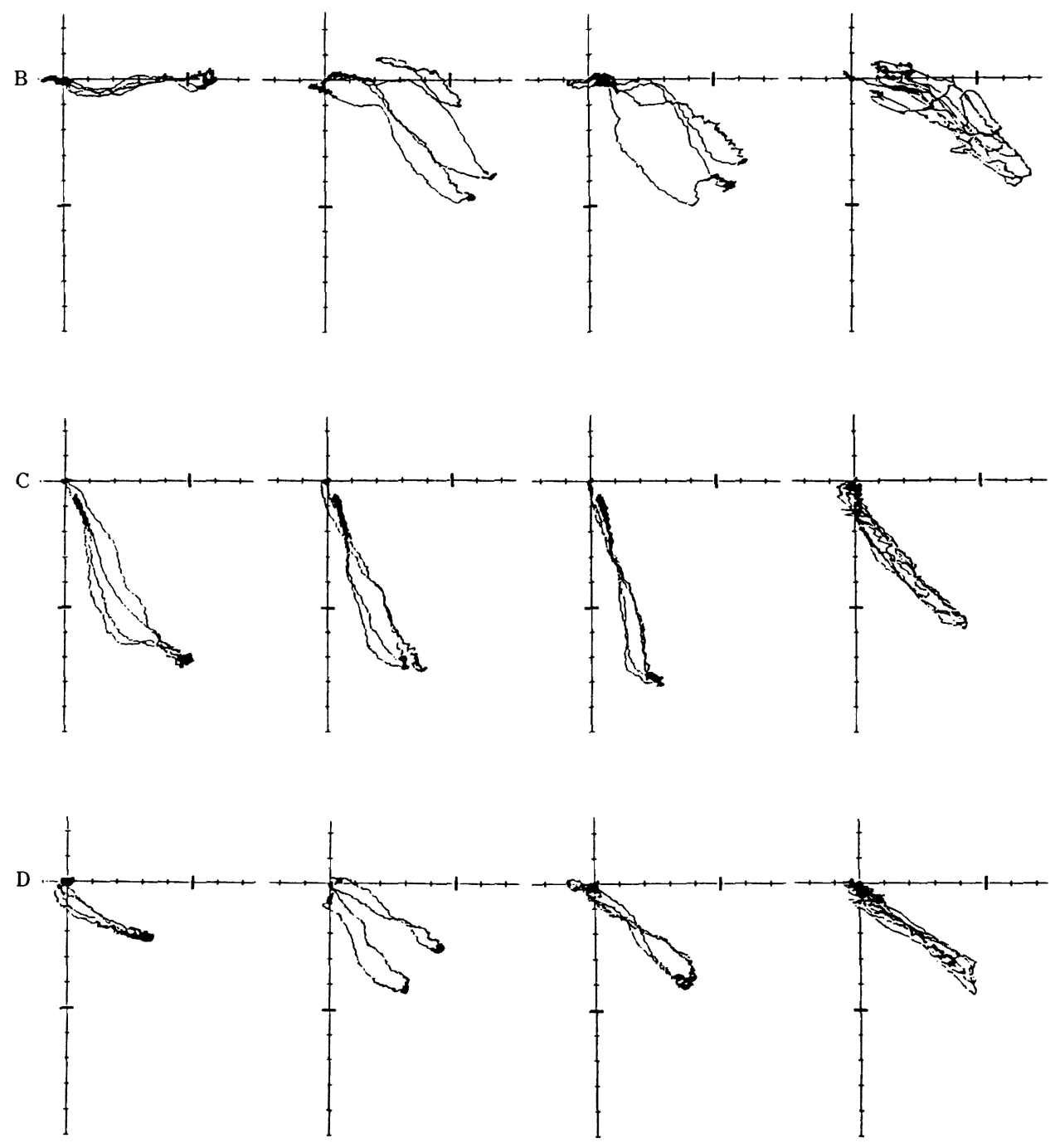

图 14 連結固定後の機能時の変位経路（上額右側第 2 小曰歯） 
連結固定が歯牙の変位様相に及ほす影響

$33-33$

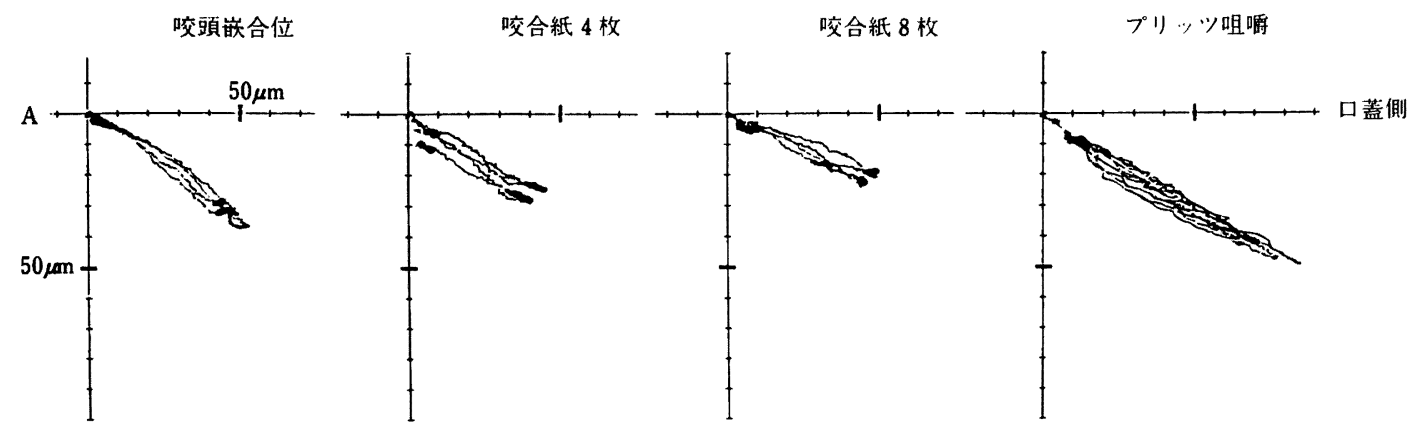

遠心
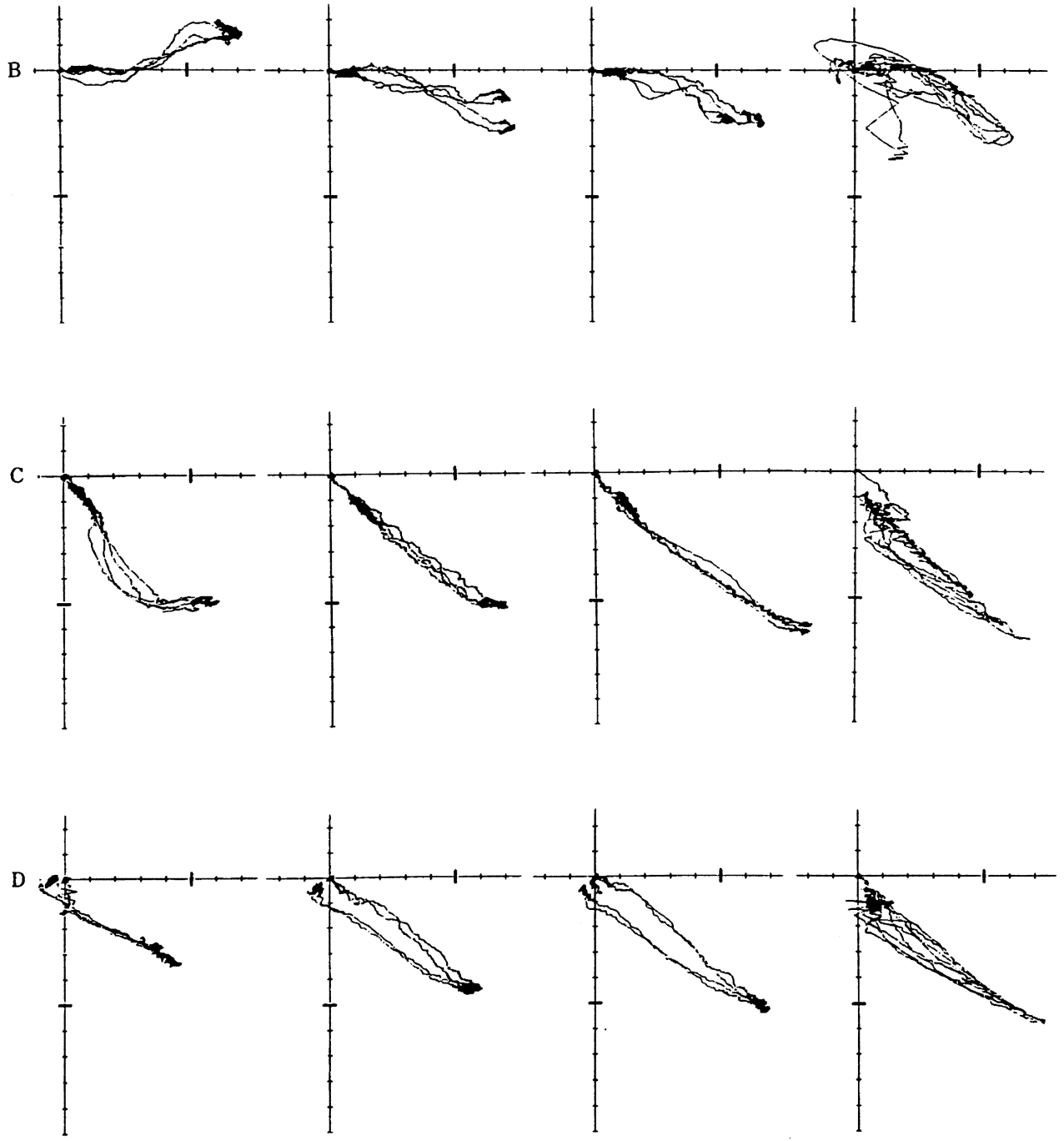

园 15 連結固定後の機能時の変位経路（上䫑右側第 1 大臼歯） 
表 2 連結固定前の上頼右側第 2 小臼歯の機能時の変位量と変 位方向

\begin{tabular}{|c|c|c|c|c|c|c|c|c|}
\hline 測定項目 & \multicolumn{2}{|c|}{$\begin{array}{c}\text { SUB. A } \\
\text { 変位量 方向 }\end{array}$} & \multicolumn{2}{|c|}{$\begin{array}{c}\text { SUB. B } \\
\text { 変位量 方向 }\end{array}$} & \multicolumn{2}{|c|}{$\begin{array}{c}\text { SUB.C } \\
\text { 変位量 方向 }\end{array}$} & \multicolumn{2}{|c|}{$\begin{array}{c}\text { SUB.D } \\
\text { 変位量 方向 }\end{array}$} \\
\hline 咬頭嵌合位 & 36 & 198 & 60 & 196 & 82 & 235 & 50 & 212 \\
\hline 咬合紙 4 枚 & 52 & 191 & 76 & 224 & 90 & 248 & 65 & 233 \\
\hline 8 枚 & 65 & 203 & 77 & 230 & 95 & 254 & 80 & 246 \\
\hline プリッツ咀曙 & 32 & 227 & 63 & 209 & 87 & 226 & 70 & 229 \\
\hline
\end{tabular}

表 3 連結固定前の上䫭右側第 1 大臼歯の機能時の変位量と変

\begin{tabular}{|c|c|c|c|c|c|c|c|c|}
\hline 測定項目 & \multicolumn{2}{|c|}{$\begin{array}{c}\text { SUB. A } \\
\text { 変位量 方向 }\end{array}$} & \multicolumn{2}{|c|}{ SUB. B } & \multicolumn{2}{|c|}{ SUB. C } & \multicolumn{2}{|c|}{ SUB. D } \\
\hline 咬頭嵌合位 & 57 & 225 & 57 & 171 & 76 & 222 & 27 & 200 \\
\hline 咬合紙 4 枚 & 34 & 207 & 47 & 162 & 78 & 221 & 60 & 208 \\
\hline 8 枚 & 39 & 207 & 63 & 200 & 78 & 224 & 81 & 208 \\
\hline プリッッ咀罣 & 92 & 205 & 44 & 213 & 83 & 224 & 77 & 207 \\
\hline
\end{tabular}

表 4 連結固定後の上䫑右側第 2 小臼䍘の機能時の変位量と変

\begin{tabular}{|c|c|c|c|c|c|c|c|c|}
\hline \multirow{2}{*}{$\frac{\text { 測定項目 }}{\text { 咬頭嵌合位 }}$} & \multicolumn{2}{|c|}{$\begin{array}{c}\text { SUB. A } \\
\text { 変位量 方向 }\end{array}$} & \multicolumn{2}{|c|}{$\begin{array}{c}\text { SUB. B } \\
\text { 変位量 方向 }\end{array}$} & \multicolumn{2}{|c|}{$\begin{array}{c}\text { SUB. C } \\
\text { 変位量 方向 }\end{array}$} & \multicolumn{2}{|c|}{$\begin{array}{c}\text { SUB. D } \\
\text { 変位量 方向 }\end{array}$} \\
\hline & 41 & 192 & 60 & 180 & 87 & 236 & 41 & 214 \\
\hline 咬合紙 4 枚 & 49 & 189 & 77 & 214 & 84 & 246 & 53 & 223 \\
\hline 8 枚 & 66 & 190 & 71 & 212 & 86 & 251 & 55 & 227 \\
\hline プリッツ咀罢 & 59 & 205 & 80 & 208 & 73 & 234 & 63 & 224 \\
\hline
\end{tabular}

\section{1. 連結固定前の歯牙の变位}

1) 上枵第 2 小臼歯

咬頭嵌合位での嚙みしめ時に上顎第 2 小臼歯の測定 点の変位量は $36 \sim 82 \mu \mathrm{m}$ であった。変位方向は被験 者 $\mathrm{A}, \mathrm{B}$ で口蓋側方向を, 被験者 $\mathrm{C}, \mathrm{D}$ では遠心口蓋 側方向を示した．変位経路はいずれの被験者において も 1 相性であった。

咬合紙 4 枚, 8 枚の嚙みしめ時に測定点の変位量は 52 95 $\mu \mathrm{m}$ を示し, 咬頭嵌合位での嚙みしめ時より やや大きかった．変位方向は被験者 Aで口蓋側方向 を, 被験者 $\mathrm{B}, \mathrm{C}, \mathrm{D}$ で遠心口蓋側方向を示したが, いずれも咬頭嵌合位での嚙みしめ時より遠心へ向かう 傾向にあった。変位経路は被験者 B を除いては 1 相性 であった。

プリッッ咀嚼時の測定点の変位量は $32 \sim 87 \mu \mathrm{m}$ で, 咬頭嵌合位での嚙みしめ時とほほ同様の結果となっ た。変位方向はいずれの被験者にあっても遠心口蓋側 方向を示し, 咬頭嵌合位での嚙みしめ時より遠心へ向 かう傾向にあった．各被験者の変位量はいずれの機能 時においても被験者 B，Cで比較的大きく, 被験者 $\mathrm{A}$ ，Dで小さかった.

\section{2）上影第 1 大臼歯}

咬頭嵌合位での嚙みしめ時に，上䫑第 1 大臼柬の測
表 5 連結固定後の上頼右側第 1 大臼歯の機能時の変位量と変 位方向 [変位量 $: \mu \mathrm{m}$, 方向: 度]

\begin{tabular}{|c|c|c|c|c|c|c|c|c|}
\hline \multirow{2}{*}{ 湘定項目 } & \multirow{2}{*}{\multicolumn{2}{|c|}{$\begin{array}{c}\text { SUB. A } \\
\text { 変位量 方向 }\end{array}$}} & \multicolumn{2}{|c|}{ SUB. B } & \multicolumn{2}{|c|}{ SUB. C } & \multicolumn{2}{|c|}{ SUB. D } \\
\hline & & & 変位量 & 方向 & 変位量 & 方向 & 変位量 & 方向 \\
\hline 咬頭嵌合位 & 62 & 215 & 72 & 169 & 77 & 220 & 56 & 217 \\
\hline 咬合紙 4 枚 & 51 & 212 & 75 & 193 & 86 & 218 & 74 & 218 \\
\hline 8 枚 & 53 & 205 & 66 & 198 & 106 & 216 & 86 & 217 \\
\hline プリッッ咀噌 & 99 & 210 & 69 & 203 & 96 & 223 & 94 & 219 \\
\hline
\end{tabular}

表 6 連結固定による上顎右側第 2 小臼歯の機能時の変位量と

\begin{tabular}{|c|c|c|c|c|c|c|c|c|}
\hline 測定項目 & \multicolumn{2}{|c|}{$\begin{array}{c}\text { SUB. A } \\
\text { 変位量 方向 }\end{array}$} & \multicolumn{2}{|c|}{ SUB. B } & \multicolumn{2}{|c|}{$\begin{array}{c}\text { SUB.C } \\
\text { 変位量 方向 }\end{array}$} & \multicolumn{2}{|c|}{$\begin{array}{c}\text { SUB.D } \\
\text { 変位量 方向 }\end{array}$} \\
\hline 咬頭嵌合位 & +5 & -6 & 0 & -16 & +5 & +1 & -9 & +2 \\
\hline 咬合紙 4 枚 & -3 & -2 & +1 & -10 & -6 & -2 & -12 & -10 \\
\hline 8 枚 & +1 & -13 & -6 & -18 & -9 & -3 & -25 & -19 \\
\hline フリッッッ咀嗂 & +27 & -22 & +17 & -1 & -14 & +8 & -7 & -5 \\
\hline
\end{tabular}

定点の変位量は $27 \sim 76 \mu \mathrm{m}$ であった. 変位方向は被 験者 $\mathrm{A}, \mathrm{C}, \mathrm{D}$ で遠心口蓋側方向を示し, 被験者 Bで 口蓋側方向を示した。変位経路はすべて 1 相性であっ た.

咬合紙 4 枚， 8 枚の嚙みしめ時に測定点の変位量は

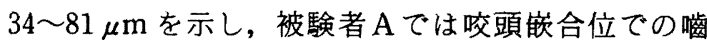
みしめ時より小さくなったが，被験者 $\mathrm{B}, \mathrm{C}, \mathrm{D} て ゙ は$ 咬頭嵌合位での嘴みしめ時より大きくなる傾向にあっ た. 変位方向はいずれも遠心口蓋側方向を示したが, 被験者 $\mathrm{B}$ の咬合紙 4 枚の嚙みしめ時だけは口蓋側方向 を示した。また，咬頭嵌合位での嚙みしめ時に比べる と, 被験者 $\mathrm{A} て ゙ は$ 近心方向となったが, 被験者 $\mathrm{B}$, C，Dではいずれも遠心方向への傾向を示した。

プリッツ咀嚼時の測定点の変位量は 44 92 $\mu \mathrm{m}$ を 示し, 被験者 $\mathrm{A}, \mathrm{C}, \mathrm{D}$ では咬頭嵌合位での喵みしめ 時より大きくなったが，被験者 Bでは逆に小さくなっ た．変位方向はすべての被験者で遠心口蓋側方向を示 したが，被験者 Aでは咬頭嵌合位での嚙みしめ時より 近心へ, 被験者 B，C，Dではやや遠心へ向かう傾向 を示した。

各被験者の変位量はいずれの機能時においても被験 者Cで比較的大きかった.

\section{2. 連結固定後の歯牙の变位}

1）上顎第 2 小臼歯

咬頭嵌合位での啮みしめ時に上䝷第 2 小臼歯の測定 点の変位量は $41 \sim 87 \mu \mathrm{m}$ を示し, 連結固定前と比べ てほほ同様の結果となった（表 6 ）。変位方向は被験 者 $\mathrm{A} ， \mathrm{~B}$ で口蓋側方向を，また被験者 $\mathrm{C} ， \mathrm{D} て ゙$ 遠心口 蓋側方向を示し, 被験者 $\mathrm{B} て は$ 連結固定前よりも $16^{\circ}$ 
表 7 連結固定による上顎右側第 1 大臼曾の機能時の変位量と 変位方向の変化

\begin{tabular}{|c|c|c|c|c|c|c|c|c|}
\hline \multicolumn{3}{|c|}{ 変位方问の哛化 } & \multicolumn{4}{|c|}{ 変位量： $\mu \mathrm{m}$, } & \multicolumn{2}{|c|}{ 方向：度] } \\
\hline \multirow{2}{*}{ 测定項目 } & \multicolumn{2}{|c|}{ SUB. A } & \multirow{2}{*}{\multicolumn{2}{|c|}{$\begin{array}{c}\text { SUB. B } \\
\text { 変位量 方向 }\end{array}$}} & \multicolumn{2}{|c|}{ SUB. C } & \multicolumn{2}{|c|}{ SUB. D } \\
\hline & & & & & 変位量 & 方向 & 変位量 & 方向 \\
\hline 咬頭嵌合位 & +7 & -10 & +15 & -2 & +1 & -2 & +29 & +17 \\
\hline 咬合紙 4 枚 & +17 & +5 & +28 & +31 & +8 & -3 & +14 & +10 \\
\hline 8 枚 & +14 & -2 & +3 & -2 & +28 & -8 & +5 & +9 \\
\hline プリッッ咀噒 & +7 & +5 & +25 & -10 & +13 & -1 & +17 & +12 \\
\hline
\end{tabular}

近心方向へ変化したが, 被験者 $\mathrm{A}, \mathrm{C}, \mathrm{D}$ では大きな 変化はみられなかった。

咬合紙 4 枚, 8 枚の嚙みしめ時に測定点の変位量は 49 86 $\mu \mathrm{m}$ を示し, 連結固定前に比べて被験者 Dで は 12〜25 $\mu \mathrm{m}$ ほど小さくなったが, 被験者 $\mathrm{A}, \mathrm{B}$, Cでは大きな変化はみられなかった。変位方向は被験

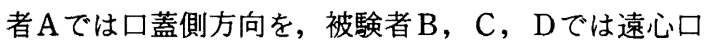
蓋側方向を示し, 被験者 $\mathrm{A}, \mathrm{B}, \mathrm{D}$ で連結固定前より

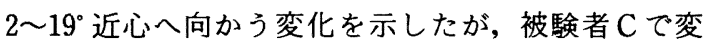
化はほとんど認められなかった。

プリッッ咀噮時の測定点の変位量は $59 \sim 80 \mu \mathrm{m}$ を 示し, 被験者 $\mathrm{A}, \mathrm{B}$ では連結固定前に比べて $17 \sim 27$ $\mu \mathrm{m}$ 大きくなったが, 被験者 $\mathrm{C}, \mathrm{D} て ゙ は 7 〜 14 \mu \mathrm{m}$ 小 さくなった，変位方向はすべて遠心口蓋側方向を示 し, 被験者 Aでは連結固定前より $22^{\circ}$ の近心への変化

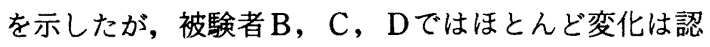
められなかった。

各被験者の変位量は連結固定後も連結固定前と同様 に被験者 $\mathrm{B}, \mathrm{C}$ では比較的大きく被験者 $\mathrm{A}, \mathrm{D}$ では小 さかった，また，変位方向は連結固定前と同様に咬頭

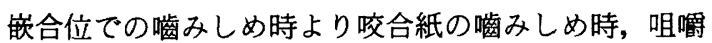
時に遠心に向かう傾向を示した。

\section{2）上顎第 1 大臼歯}

咬頭嵌合位での啮みしめ時に上額第 1 大臼歯の測定 点の変位量は 56〜 77 $\mu \mathrm{m}$ を示し, 連結固定前に比べ て被験者 B，Dでは 15〜29 $\mu \mathrm{m}$ 大きくなったが，被.

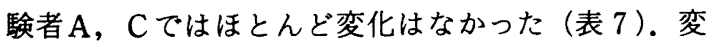
位方向は被験者 $\mathrm{A}, \mathrm{C}, \mathrm{D} て ゙$ 遠心口蓋側方向を, 被験 者 Bで近心口蓋側方向を示し, 被験者 Dでは連結固定 前と比べて $17^{\circ}$ 遠心方向へ変化したが, 被験者 $\mathrm{A}$,

B，Cでは大きな変化はみられなかった。

咬合紙 4 枚, 8 枚の䕬みしめ時に測定点の変位量は 51 106 $\mu \mathrm{m}$ を示し, 連結固定前に比べて全被験者と も大きくなり, 被験者 $\mathrm{B}, \mathrm{C}$ は被験者 $\mathrm{A}, \mathrm{D}$ より大き く 3〜28 $\mu \mathrm{m}$ の変化を示した. 変位方向はすべて遠心 口蓋側方向を示し, 連結固定前に比べて被験者 Bは咬
合紙 4 枚の嚙みしめ時に $31^{\circ}$ の遠心への変化を示した が, 被験者 $\mathrm{A}, \mathrm{C}, \mathrm{D}$ で変化はほとんどみられなかっ た。

プリッッ咀礵時の測定点の変位量は $69 \sim 99 \mu \mathrm{m}$ を 示し, 連結固定前に比べて全被験者とも大きくなり, 被験者 B，C，Dでは 13〜25 $\mu \mathrm{m}$ の変化を示した. 変位方向はすべて遠心口蓋側方向を示し, 被験者 $\mathrm{D}$ は 連結固定前に比べて $12^{\circ}$ 遠心方向への変化を示した。

各被験者の変位量はいずれの機能時においても、被験 者Cで比較的大きかった。また，変位方向は連結固定 前と同様に咬頭嵌合位での嚙みしめ時より，咬合紙の 嚙みしめ時, 咀嚼時にわずかに遠心に向かう傾向を示 した.

\section{IV. 考察}

ブリッジ補経は歯牙への固定性から機能回復の程度 が高く,また装着感がよいことから, 重要な補綴方法 として位置づけられている。

ブリッジ補経に際しては固定性, 半固定性にかかわ らず，複数の歯牙を何らかのかたちで連結固定するの が常である、したがって，ブリッジ補緅による歯牙の 連結固定が正常な歯周組織の機能時の動態にいかなる 影響を及ほしているのかという問題は，ブリッジを設 計，作製していくうえで知らねばならない重要な研究 課題となっている．和賀ら ${ }^{8)}$ は下顎臼歯部に実際にブ リッジを装着して, 前頭面方向からの支台歯の変位の 測定を行い, 変位量は減少し, 変位方向は変化すると 報告している。

ブリッジの装着に伴う支台歯の変位経路の変化には 歯牙の連結固定, 支台歯の咬合面形態の変化, 隣接歯 間関係の変化，ポンティックの咬合面形態そしてブ リッジ自体の精度などの影響が錯綜して現れるものと 考えられる。したがって，これらの各要因をそれぞれ に分離，分析することによってブリッジ補緅の歯周組 織, 顎口腔系における機能的意義が解明されていくこ とになろう。

そこで, 著者は咬合接触関係を妨げない連結固定装 置を考案, 作製して歯牙に適用し， 2 次元微小変位計 $\mathrm{M}-\mathrm{r}$ 型で歯牙の変位経路を測定して, 歯牙の連結固 定の前後における歯周組織の動態を比較検討すること とした。 


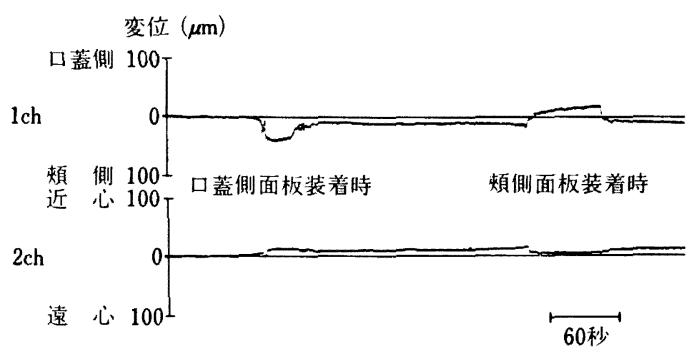

図 16 連結固定装置装着時の変位出力 （被験者 C 上䫂右側第 1 大臼歯）

\section{1. 研究方法}

1) 連結固定装置

本実験の目的はブリッジ補綴などに伴う歯牙の連結 固定が歯牙の変位に及ぼす影響を検討することにある ので，連結固定時に起こり得る歯牙の咬合接触状態や 隣接歯間関係の変化を排除しなければならない。ま た，歯牙の変位を測定する標点は，歯牙の連結固定の 前後において同一位置にあることが必要である。

今回作製した連結固定装置は咬合面を覆うことな く，また隣接接触点からも十分に離した煩側面板と口 蓋側面板とからなる構造となっていて，煩側面，口蓋 側面から上顎第 2 小臼歯，第 1 大臼歯，第 2 大田歯の 3 歯の連結固定を行う。また，煩側面板，口蓋側面板 は厚さ約 $1.5 \mathrm{~mm}$ のタイプIV金合金製で実験中にたわ むこともなく，各実験後に離脱していたこともなかっ たので，強固に歯牙を連結固定できていたものと考え られる。

歯牙の変位を測定する標点は上顎第 2 小臼歯, 第 1 大臼歯の煩側歯頸部中央に設定したが，連結固定装置 の㥧側面板はこれらの標点を避けるように作製してあ るので，歯牙の連結固定の前後に同じ標点について変 位の測定が行える。

連結固定装置の口蓋側面板および煩側面板の歯牙へ の装着時に各歯牙の標点は変位を示した（図 16）。こ の変位を測定した結果が表 $8 て ゙ ，$ 標点の変位は歯牙の 連結固定の前後で 3 $22 \mu \mathrm{m}$ であった。これは連結固 定装置の寸法精度, 装着操作などに原因するものと考 えられるが，変位距離は最大でも $22 \mu \mathrm{m}$, 多くの場 合に $10 \mu \mathrm{m}$ 前後ということから，歯牙は連結固定装 置によってほとんど動かされることはなかったものと 考えられる．また，歯牙の連結固定後に採得したシリ コーン・ブラック法による咬合接触状態も連結固定前 の状態（図1）に比べてほとんど変化していなかっ た．以上のことから，この連結固定装置の開発，作製
表 8 連結固定装置装着時にみられる標点の変位量

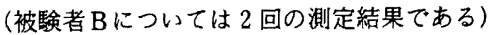

$(\mu \mathrm{m})$

\begin{tabular}{crrrr}
\hline \hline 被験者 & $\mathrm{A}$ & $\mathrm{B}$ & $\mathrm{C}$ & $\mathrm{D}$ \\
\hline 5 & 12 & 11,22 & 7 & 5 \\
6 & 3 & 4,8 & 13 & 4 \\
\hline
\end{tabular}

によって, 本研究の目的である歯牙の変位への歯牙の 連結固定に限った影響を検討できるといえよう。

2）歯牙の変位の測定

歯牙の変位の測定は上顎第 2 小臼歯ならびに第 1 大 臼歯について, 水平面内で行った。 上顎第 2 小臼歯, 第 1 大臼歯の変位量は, 加藤4,5)の前頭面内での測定 で 63〜123 $\mu \mathrm{m}$ ，三浦6)の水平面内での測定で 10 146 $\mu \mathrm{m}$ と報告されていて，下澦の 40〜95 $\mu \mathrm{m}, 16 \sim 91$ $\mu \mathrm{m}$ に比べて大きく，連結固定による歯牙の変位量の 変化の測定に適している。また，歯牙の変位はいうま でもなく 3 次元的に起こるが，歯牙の連結固定による 変化は，ブリッジなどの連結固定法の性質から水平面 内に大きく現れるものと考えられる.

歯牙の変位の測定は三浦 $\left.{ }^{6}\right)$ の 2 次元微小変位計 $\mathrm{M}$ 型 を改変して，新たに作製した 2 次元微小変位計 $\mathrm{M}-\mathrm{r}$ 型を使用した。変位計の近遠心, 煩舌両方向の出力は 相互に干涉することなく， $\pm 400 \mu \mathrm{m}$ の範囲内におい て $\pm 2 \%$ 以下の高精度で感度方向の変位に対してリニ アな出力を示すことから（図 7〜9）, 歯牙の水平面内 での変位の測定に対しては十分な精度をもつものと考 えられる。

変位計は総重量が $51 \mathrm{~g}$ と軽量かつ小型であること に加えて，歯牙に加わる測定圧も $3 \mathrm{~g}$ 以下となるの で，変位計が歯牙本来の動きを妨げることはほとんど ない.

以上のことから，本測定装置は本研究の目的にとっ て十分なものといえよう。

\section{2. 連結固定前の歯牙の変位}

上䫟第 2 小臼歯, 第 1 大臼歯の測定点は喵みしめ時 に27 95 $\mu \mathrm{m}$, プリッッ咀嚼時に 32 $92 \mu \mathrm{m}$ の変位 量を示した（表 $2 ， 3$ ）．変位量は被験歯ごとに異なっ ていたが，いずれも三浦6が被験者 7 名について水平 面内で測定した変位量とほほ同等の結果となってい た.

変位方向は嚙みしめ時, 咀嘪時に口蓋側方向から, 口蓋側遠心方向へ向かい（図 $12 ， 13$ ）, 臼歯部は全体 


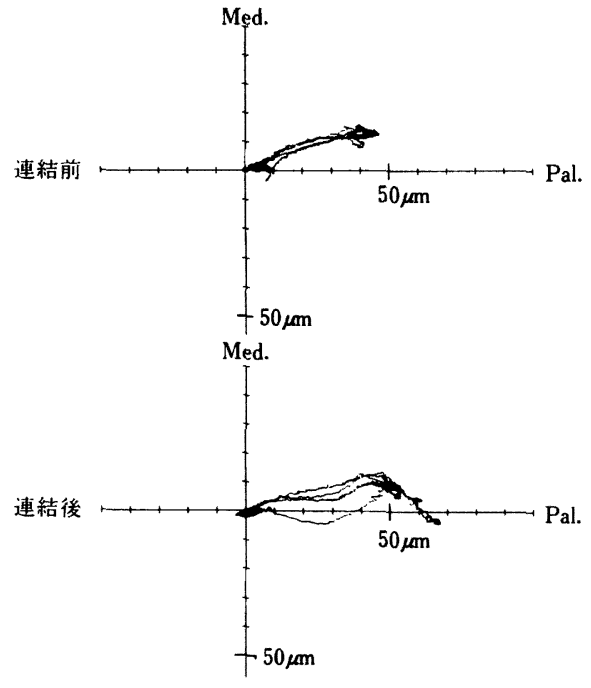

图 17 上顥右側第 2 小臼菌で咬合紙 8 枚を噌みしめ たときの第 1 大臼歯の変位経路（被験者 B)

として遠心口蓋側へ向かうとする三浦占の知見とほほ 一致していた.

以上のことから, 本実験のすべての被験歯は, 連結 固定されていない1歯，1歯として機能時に正常な歯 周組織の動態を示していたものと考えられる。

\section{3. 連結固定による歯牙の変位様相の变化}

歯牙の連結固定後の変位量は, 歯牙の固定前に比べ て上䋶第 2 小臼歯では被験者 $\mathrm{A}, \mathrm{B} て ゙$ 咀罚時に 17 $27 \mu \mathrm{m}$ の増加を示したが, 嚙みしめ時にはほとんど 変化をみせなかった。また, 被験者 $\mathrm{C}, \mathrm{D}$ は歯牙の連 結固定後に逆に変位量の隇少傾向を示した (表 6). 第 1 大臼歯では歯牙の連結固定前に比べて, 変位量は 全被験者で 1〜29 $\mu \mathrm{m}$ の増加を示した（表 7 ）.

変位方向は歯牙の連結固定前に比べて上顎第 2 小臼 歯では被験者 Cはほとんど変化を示さなかったが, 被 験者 $\mathrm{A}, \mathrm{B}, \mathrm{D}$ は+2 - $22^{\circ}$ の近心方向への変化傾 向をみせた (表 6 ). 第 1 大臼歯では歯牙の連結固定 前に比べて被験者 $\mathrm{A}, \mathrm{C}$ はほとんど変化をみせなかっ たが, 被験者 $\mathrm{D}$ は 9 17 の遠心方向への変化を, 被 験者 $\mathrm{B}$ は $-10 \sim+31^{\circ}$ と方向の定まらない変化を示し た (表 7$)$.したがって, 歯牙の連結固定前の変位経 路は歯牙の連結固定によって, 変位量, 変位方向ある いはその双方に何らかの変化が起こるといえる.

歯牙は機能時には歯槽骨の中へ押し込まれながら歯 列弓の幅径を狭める方向へ変位するとともに, 安静時

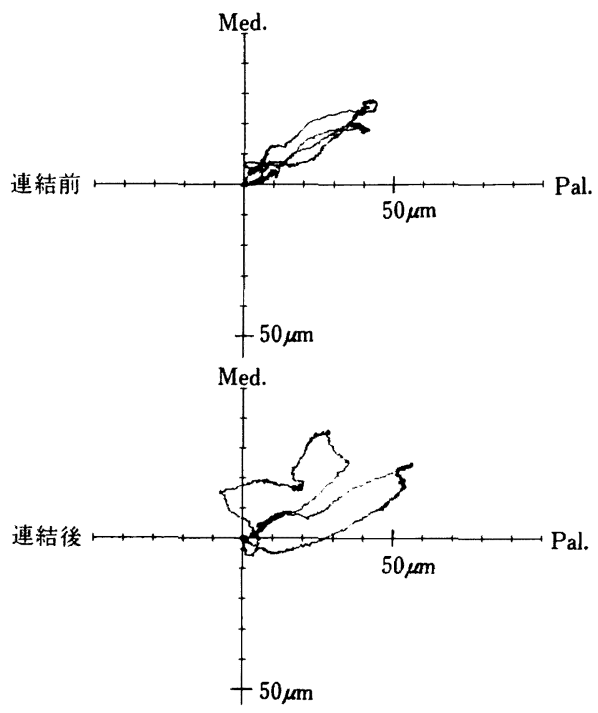

図 18 上罘右側第 2 大臼歯で咬合紙 8 枚を䱣みしめ たときの第 1 大臼歯の変位経路（被験者 B）

に空隙があった隣接歯間は緊密な接触状態となること は三浦》の研究結果などから知られている. 歯牙の連 結固定は各歯牙の安静時に行われるので, 歯牙は機能 時に隣接歯間距離を狭めることができず, 連結固定前 とは異なる変位経路をとることになる，そして，この 歯牙の変位経路の変化に伴って, 連結固定された歯牙 と隣接する歯牙との歯間関係にも何らかの影響が及ん でいるものと考えられる.

また，歯牙は通常その咬合面で受ける咬合力だけか らではなく隣接歯に加わる咬合力からの影響も受けて 変位を示している. 図 17,18 は被験者 Bについて上 顎第 2 小臼歯および第 2 大臼歯で咬合紙 8 枚の嚙みし めを行ったときの上顎第 1 大臼歯の測定点が示す変位 経路を歯牙の連結固定の前後に測定した結果である. 連結固定前の第 1 大臼歯は第 2 小臼歯, 第 2 大臼歯の いずれでの咬合紙の啮みしめ時にも $40 \mu \mathrm{m}$ 程度の変 位量を示し, 第 2 大臼歯での啮みしめ時にはより近心 に向かう変位方向となった，ここで，噙ませた咬合紙 は 8 枚と厚く, 最大に啮みしめても第 1 大臼歯自体が 咬合接触したとは考えにくい.したがって, 第 1 大臼 歯の変位は隣接接触点および歯周組織を通じての咬合 力の伝達に に第 1 大臼歯の変位経路は変化を示し, 変位量は 7〜 $13 \mu \mathrm{m}$ 増加して, 変位方向は約 $10^{\circ}$ 近心へ向かう傾向 を示した.

以上のことから，歯牙の連結固定による変位経路の 
$38-38$
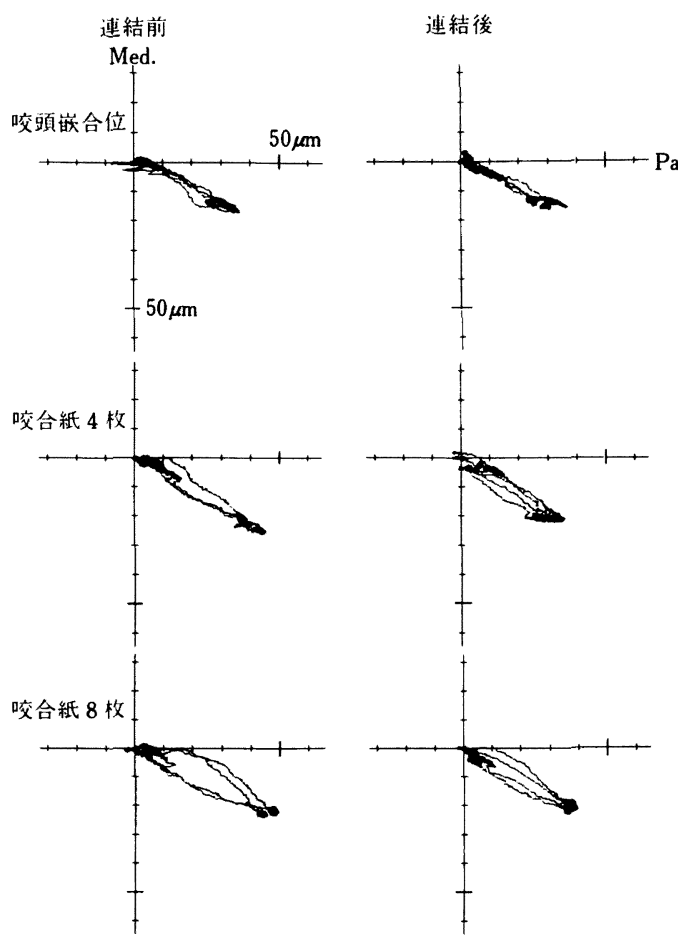

图 19 上頞右側第 2 小曰歯と第 1 大臼歯を連結固定したとき の第 1 大臼歯の変位経路（被験者 $\mathrm{A}$ )

変化は, 連結固定によって本来の機能時に各歯牙が示 す歯間距離を狭める，近遠心方向の変位を妨げられる こと，隣接歯に加わった咬合力が隣接接触点および歯 槽骨を含む歯周組織を介して伝達される機序を抑えら れることなどに起因しているものと考えられる。

各被験歯の変位経路は連結固定後にさまざまな変化 を示したが，これは上顎第 2 小臼歯, 第 1 大臼歯, 第 2 大臼歯の 3 歯を連結したためと考えられる.図 19

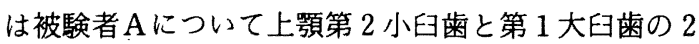
歯だけを連結固定して，その前後に嚙みしめ時の第 1 大臼歯の測定点の変位経路を測定した結果である。連 結固定の前後で変位量は 3 10 $\mu \mathrm{m}$ の減少を, 変位方 向は $-2 \sim+6^{\circ}$ の変化を示した（表 9 ). 連結固定に よる歯牙の変位経路の変化は, 3 歯の連結固定の際 （表 7 ）に比べてやや小さいが,これは隣接する変位 経路が類似した 2 歯を連結固定したことによるものと 考えられる.したがって, 連結固定する歯牙を 3 歯か ら 4 歯と増加したり,あるいは離れた位置にある,隣接 していない歯牙を連結固定すれば，歯牙の変位経路は さらに複雑な連結固定による変化を示すことになろう。
37 巻 1 号 (1993)

表 9 上顥右側第 2 小臼歯, 第 1 大臼歯の 2 歯を連結固定 した前後の変位量, 変位方向およびその間の変化量 （被験者 $\mathrm{A}$ ，上顓右側第 1 大臼雪）

〔変位量 : $\mu \mathrm{m}$, 方向 : 度〕

\begin{tabular}{lc|cc|cc|cc}
\hline \hline \multirow{2}{*}{ 測定項目 } & \multicolumn{2}{|c|}{ 連結前 } & \multicolumn{2}{|c|}{ 連結後 } & \multicolumn{2}{c}{ 変化量 } \\
& 変位量 & 方向 & 変位量 & 方向 & 変位量 & 方向 \\
\hline \multicolumn{2}{|l|}{ 咬頭嵌合位 } & 39 & 207 & 36 & 205 & -3 & -2 \\
咬合紙 & 4 枚 & 46 & 210 & 38 & 216 & -8 & +6 \\
& 8 枚 & 54 & 205 & 44 & 210 & -10 & +5 \\
\hline
\end{tabular}

\section{4. 歯牙の連結固定と歯周組織の動態}

歯牙は咬頭嵌合位での嚙みしめ時, 咬合紙の啮みし め時など同一の機能時にあるいはまた異なる機能時に 同じ変位経路を示すことはまれである（図 12，13）. これは機能時に発揮される咬合力の差異あるいは咬合 接触関係のわずかな変化によって生ずることで5,6,10), 非生理的な現象ではない。むしろ，正常な歯周組織を もつ歯牙は各種の機能時にある一定の範囲内，生理的 な範囲内に変位経路を描くものと考えられる.

そこで, 生理的な機能を代表して咬頭嵌合位での啮 みしめ時, 咬合紙 4 枚, 8 枚を介しての谿みしめ時の 各 2 回の歯牙の変位経路, そしてプリッツ咀緭時の初 期 4〜 5 ストロークに対応する歯牙の連結固定前の変 位経路を原点で重ね合せ，その外側を連ねた輪郭を歯 牙の変位経路の分布範囲, 生理的分布範囲とした（図 20).この生理的な分布範囲に対して歯牙の連結固定 後の変位経路の分布範囲を比較検討する.

上顎第 2 小臼歯の変位経路の生理的な分布範囲は被

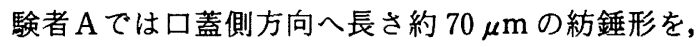
被験者 B，C，Dでは遠心口蓋側方向へ高さ約 80〜 $95 \mu \mathrm{m}$ の原点を頂点とする類三角形となった．第 1 大臼歯の生理的分布範囲は被験者 $\mathrm{A}, \mathrm{C}, \mathrm{D} て ゙ は$ 遠心 口蓋側方向へ長さ約 80 90 $\mu \mathrm{m}$ の紡錘形を，被験者

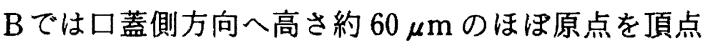
とする類三角形となった，被験者 Bで第 2 小臼歯，第 1 大臼歯とも近遠心方向に比較的幅の広い生理的分布 範囲を示したが，これは歯間離開度が関係してのこと と考えられる(図 1).

変位経路の生理的分布範囲に歯牙の連結固定後の変 位経路の分布範囲を重ね合せると（図 20），第 2 小臼 歯では全被験者で連結固定後の分布範囲は生理的分布 範囲内にほとんど包含された。一方，第 1 大臼歯では 被験者 $\mathrm{A}$ を除いて, 連結固定後の変位経路の分布は生 理的分布範囲外にまで及び, 被験者 B，Cでは口蓋側 方向へ約 15〜25 $\mu \mathrm{m}$ ほど拡大した。そして, 被験者 
5

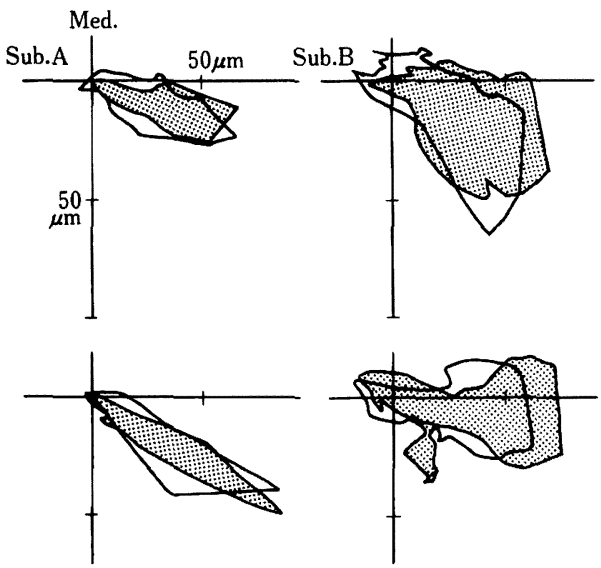

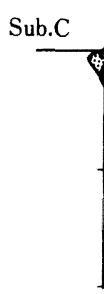

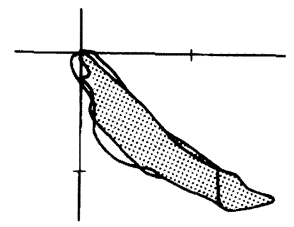

連結前
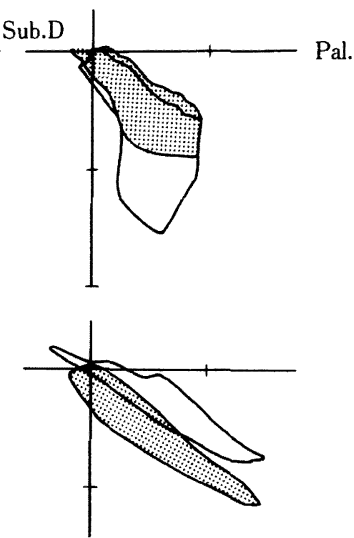

連結後

図 20 変位経路の分布範囲

Dでは約 $10^{\circ}$ 遠心方向に全体として回転したような範

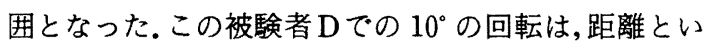

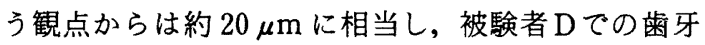
の連結固定後の変位経路の分布は生理的分布範囲に対 して被験者 $\mathrm{B}, \mathrm{C}$ とほほ同等の状況にあることになる。

被験者 $\mathrm{B}, \mathrm{C}, \mathrm{D}$ の第 1 大臼歯にみられた生理的分 布範囲に対する歯牙の連結固定後の変位経路の分布範 囲の差異である $20 \mu \mathrm{m}$ は, $20 \sim 50 \mu \mathrm{m}^{11}$ あるいは 8 $\sim 30 \mu \mathrm{m}^{12)}$ といわれる歯根膜の判別闇，また顎口腔系 での機能状況から導かれた $30 \mu \mathrm{m}$ といわれる咬合の 精度 ${ }^{10,13)}$ などから考えるとき，歯周組織が許容できる 範囲内の数值であるとしても大過なかろう.

歯牙の個々の機能時の変位経路に対する歯牙の連結 固定の影響を検討していくと, 変位量で $29 \mu \mathrm{m}$, 変 位方向で $31^{\circ}$ と比較的大きい変化を示すものもある (表 6，7). しかし, 各変位経路を全体的に比較する と変位量の大きい歯牙は連結固定後にも変位量は大き く, 咬頭嵌合位での嘴みしめ時より咬合紙あるいはプ リッツ咀哷時に遠心へ向かうという変位方向での傾向 も歯牙の連結固定後にまたみられる（表 2〜5). した がって, 歯牙の変位経路は, 歯牙の連結固定後にも大 きく変貌することはなく, 連結固定前の性状を保って いることになる。

また, 歯牙の変位経路に対して生理的分布範囲とい うものを考えれば, 歯牙の連結固定が歯周組織の動態 に対して大きな影響は及ほしていないことが分かる。

以上のことから，ブリッジ補綴などによる 3 歯程度 の歯牙の連結固定が支台歯の歯周組織に障害を与える
ことは少ないものと考えられる.

\section{V. 結 論}

歯牙の連結固定が機能時の歯牙の変位にどのような 影響を及ほすのかを明らかにする目的で，上頸第 2 小 臼歯，第 1 大臼歯，第 2 大臼歯の 3 歯を連結固定し て，第 2 小臼歯，第 1 大臼歯の 2 歯について水平面内 における変位を連結固定の前後に測定し，以下の結論 を得た。

1. 連結固定装置を作製して, 歯牙の連結固定前後 で咬合接触状態および隣接歯間関係を変化させること なく,また同一標点についての変位の測定を可能とし た.

2. 2 次元微小変位計 $M-r$ 型は, 近遠心, 顂舌方 向ともに $4000 \mu \mathrm{m}$ の範囲内において $2 \%$ 以下の精 度で感度方向の変位に対してリニアな出力を示し, 歯 牙の変位の測定に対して十分な精度を有していた。

3. 連結固定前の上額第 2 小臼歯の嚙みしめ時およ びプリッツ咀嚼時の変位量は $32 \sim 95 \mu \mathrm{m}$ で, 変位方 向は口蓋側方向から遠心口蓋側方向であった。

4. 連結固定前の上額第 1 大臼歯の嚙みしめ時およ びプリッツ咀罚時の変位量は $27 \sim 92 \mu \mathrm{m} て ゙$, 変位方 向は口蓋側方向から遠心口蓋側方向であった。

5. 連結固定後に上額第 2 小臼歯の嚙みしめ時およ びプリッッ咀嚼時の変位量はー25〜 $+27 \mu \mathrm{m} の$, 変 位方向はー22〜+8 の変化を示した。

6. 連結固定後に上顎第 1 大臼歯の嚙みしめ時およ 
びプリッツ咀嚼時の変位量は $1 \sim 29 \mu \mathrm{m}$ の, 変位方向 はー10〜+31 の変化を示した。

7. 各種機能時の上顎第 2 小臼歯, 第 1 大臼歯の変 位経路から生理的分布範囲を想定すると，その範囲は 口蓋側方向から遠心口蓋側方向へ向かう長さ約 60〜 $95 \mu \mathrm{m}$ の紡錘形あるいは類三角形を示した.

8. 変位経路の生理的分布範囲に対して歯牙の連結 固定後の変位経路を比較した結果, 多くは生理的分布 範囲内に包含され, 最も離れた経路でも $20 \mu \mathrm{m}$ 程度 の距離を示したに過ぎなかった。

9.ブリッジ補緅などによる 3 歯程度の歯牙の連結 固定が歯周組織の動態に影響を及ぼすことはほとんど ないものと考えられる。

稿を終わるに臨み、ご指導ならびにご校閲を賜りました田端 恒雄教授に謹んで感謝の意をあらわします。また，本研究に 種々ご助言頂きました第 2 補緅学教室の諸先生方に厚く御礼申 し上げます，併せて本研究にご協力頂いた被験者各位に深謝致 します。

本論文の要旨の一部は, 平成 4 年 2 月, 平成 3 年度日本補経 歯科学会関東支部学術大会において発表した.

\section{文献}

1) Mühlemann, H.R. : Periodontometry, A method for measuring tooth mobility, Oral Surg Oral Med Oral
Pathol, $4: 1220 \sim 1233,1951$.

2) Siebert, G, : Zur physiologischen Auslenkung der Zähne, Dtsch Zahnärztl Z, $35: 362 \sim 365,1980$.

3) Siebert, G. : Recent results concerning physiological tooth movement and anterior guidance, J Oral Rehabil, $8: 479 \sim 493,1981$.

4）加藤 均：歯周組織の機能状態に関する研究 第 1 報 2 次元微小変位計, 補綴誌, $25: 733 \sim 745,1981$.

5）加藤 均：歯周組織の機能状態に関する研究 第 2 報 歯の機能時の変位と安静時の脈動, 補経誌, $26: 133 \sim 147$, 1982.

6）三浦宏之：機能下にある雬牙の水平面内における変位に関 する研究, 補綴誌, $29: 735 \sim 754,1985$.

7）三浦宏之：隣接歯間関係の動態に関する研究，補綴誌， $29: 1134 \sim 1142,1985$.

8）和賀浩幸, 古川良俊, 佐藤 克ほか：橋義歯支台歯におけ る機能時の動態一固定性連結が及ほす影響一, 補綴誌, $35: 262 \sim 268,1991$.

9）三浦宏之, 古木 埕, 長谷川成男ほか：咬合力による雬周 組織の歪が隣接粷に及ほす影響, 補緅誌, 投稿予定.

10）長谷川成男：咬合学序説, 1 18, 医歯薬出版, 東京, 1988.

11) Tryde, G., Frydenberg, O., and Brill, N.: An assess. ment of the tactile sensibility in human teeth, Acta Odontol Scand, $20: 233 \sim 256,1962$.

12) Sirrilä, H.S. and Laine, P.: The tactile sensibility of the parodontium to slight axial loadings of the teeth, Acta Odontol Scand, $21: 415 \sim 429,1963$.

13）田中伐平：咬頭嵌合位における補綴物の高さが額口腔系に 及㳆す影響, 補緅誌, $19: 666 〜 692,1976$. 